\title{
HET SUGGEREREN VAN VERZOENING TIJDENS DE HOORZITTINGEN VAN DE WAARHEIDS- EN VERZOENINGSCOMMISSIE
}

\author{
Annelies Verdoolaege \\ Vakgroep Afrikaanse Talen en Culturen \\ Universiteit Gent \\ Rozier 44 \\ B-9000 Gent
}

e-mail: Annelies.Verdoolaege@Ugent.be

\section{SUMMARY}

Suggesting reconciliation at the hearings of the Truth and Reconciliation Commission

The South African Truth and Reconciliation Commission (TRC) took place under unique circumstances and in a very particular historical context. This article will explore how such a specific kind of reality gave rise to a specific kind of discourse, a so-called 'reconciliation 
discourse'. On the one hand, this discourse offered the apartheid victims a lot of opportunities regarding linguistic expression. On the other hand, though, this discourse was also regimented and limited to a certain extent. By means of fragments from the TRC victim testimonies, this article will deal with one aspect of this linguistic manipulation, namely the introduction of the concept of reconciliation. In the first part of the article, I will explain which linguistic methods were used during the TRC hearings in order to emphasize the notion of reconciliation in the narratives of the testifying victims. In doing so, a lot of attention will be paid to the concrete interaction between the testifiers and the TRC commissioners. In a second part, I will try to investigate why the construction of this specific reconciliation discourse was necessary in the South African context. We will see that, amongst others, also political considerations played a role in the control exercised over the discourse of the TRC victims. In this way, we will understand that the reconciliation discourse of the Commission was a reflection of a very ambiguous social attitude: this discourse had to reveal as much as possible about the apartheid past and this in a manner as spontaneous, as transparent and as open as possible -, but it also had to be adapted to certain socio-political needs. This will tell us that also a quasi-judicial institution such as the TRC involves an inevitable interplay between language on the one hand and ideology and society on the other.

Key Words: South Africa, Truth and Reconciliation Commission, victim testimonies, critical discourse analysis, reconciliation, apartheid

\section{INLEIDING}

$\mathrm{Na}$ de eerste democratische verkiezingen van $1994 \mathrm{kwam}$ de Waarheids - en Verzoeningscommissie van Zuid-Afrika (TRC) tot stand in 'The National Unity and Reconciliation Act' van mei 1995. De TRC werd in het leven geroepen tijdens de onderhandelingen 
tussen de National Party (NP) en het African National Congress (ANC) en haar bedoeling was af te rekenen met de wandaden gepleegd onder apartheid. Het was vooral Alex Boraine die suggereerde om te spreken over een waarheids- en verzoeningscommissie in plaats van over een waarheidscommissie. Die voorgestelde term benadrukte dat het blootleggen en erkennen van de waarheid in de eerste plaats gericht was op het tot stand brengen van vrede en verzoening (Boraine, 2000: 38). Het mandaat van de TRC, zoals beschreven in de Act, was heel ambitieus en had als belangrijkste doelstellingen het zo volledig mogelijk onthullen van de waarheid omtrent de mensenrechtenschendingen die gebeurd waren tijdens apartheid, het onder bepaalde voorwaarden verlenen van amnestie aan de daders van apartheid en het formuleren van voorstellen met betrekking tot slachtoffervergoedingen (Truth and Reconciliation Commission of South Africa Report, 1998, Volume 1/4: 54). De Commissie werd beschouwd als een brug tussen een verleden van onrecht en ellende en een toekomst gebaseerd op mensenrechten, democratie en gelijkheid; ze werd dus algemeen gezien als een van de noodzakelijke voorwaarden voor de transitie naar een nieuw Zuid-Afrika. En hoewel de Zuid-Afrikaanse TRC zeker niet de eerste waarheidscommissie was - in het verleden waren commissies al opgezet in verschillende andere Afrikaanse en ZuidAmerikaanse landen (Hayner, 2001) - is het duidelijk dat deze Commissie uniek was door haar specifieke historische en politieke context.

Het is vanzelfsprekend dat zo'n welbepaalde realiteit - het TRC fenomeen - aanleiding gaf tot een bepaald soort taalgebruik. De specifieke taal die gehanteerd werd tijdens de hoorzittingen van de TRC heb ik 'verzoeningsdiscours' genoemd. In dit artikel buig ik me over de taal van de hoorzittingen van het Comité voor Mensenrechtenschendingen, dus de zittingen waar slachtoffers voor de Commissie getuigden over hun ervaringen onder apartheid. Dit Comité was minder legalistisch dat het Amnestiecomité, waar daders van apartheidsmisdaden aan het woord werden gelaten. Die daders werden vaak onderworpen aan een kruisverhoor en lieten zich verdedigen door advocaten. Voor het Amnestiecomité werden de daders beschouwd als beklaagden en de gebruikte terminologie was juridisch 
(de Klerk, 2003a, 2003b). De slachtoffers die verschenen voor het Mensenrechtencomité werden op een andere manier behandeld. Steeds opnieuw werd benadrukt dat zij niet terechtstonden, maar enkel een forum hadden gekregen om hun verhaal te vertellen. Tijdens de getuigenis werd aandacht besteed aan de menselijke zijde van het verhaal en het taalgebruik was eerder psychologisch-religieus dan juridisch. Deze hoorzittingen waren ook informeler, de slachtoffers stonden centraal en de meeste commissarissen waren geen juristen. Desondanks deed de hele set-up van de hoorzittingen van het Comité voor Mensenrechtenschendingen toch denken aan een rechtszaak, waar de commissarissen de rol van jury vervulden en het slachtoffer de rol van getuige. Om die redenen wordt de TRC in zijn geheel vaak bestempeld als 'quasi-juridisch' (o.a. Buur, 2000).

Meer dan 1800 mannen en vrouwen vertelden hun verhaal voor het Mensenrechtencomité en alle transcripties van die getuigenissen zijn beschikbaar op de website van de TRC (http://www.doj.gov.za/trc/ trc frameset.htm). Om een zo volledig mogelijk beeld te krijgen van dat verzoeningsdiscours was het nodig al die transcripties te overlopen. Daaruit bleek duidelijk dat dit discours een aantal typische kenmerken bevatte: bepaalde onderwerpen werden aangesneden en andere niet, de taal had een bepaalde structuur, de interactie tussen de getuigen en de commissarissen nam een bepaalde vorm aan, enzovoort.

Die linguïstische kenmerken kunnen op twee verschillende manieren benaderd worden. Positief gezien waren deze hoorzittingen een unieke gelegenheid voor de apartheidsslachtoffers om hun schokkende ervaringen naar voren te brengen en dit vaak voor de eerste keer in hun leven. Voor het eerst was er ook een sympathiserend publiek aanwezig dat hun lijden erkende en dat aandacht besteedde aan wat ze vertelden. We kunnen dan ook niet ontkennen dat die zittingen uiterst belangrijk zijn geweest voor de waardigheid van de individuele slachtoffers (voor meer informatie over deze positieve aspecten van het Comité voor Mensenrechtenschendingen en van de TRC in haar geheel verwijs ik naar de website http://africana.ugent.be/trc/htm).

Als we echter met een iets kritischer ingesteldheid kijken naar die hoorzittingen, zien we dat de getuigen ook onderworpen waren aan bepaalde beperkingen bij het vertellen van hun verhaal. Hoewel de 
TRC dus beweerde dat ze een open forum bood waar slachtoffers in alle vrijheid hun gevoelens konden uiten, was het taalgebruik van de getuigen toch tot op zekere hoogte ingeperkt. Sommige beperkingen waren onvermijdelijk, rekening houdend met de praktische context van de hoorzittingen. Een probleem was bijvoorbeeld dat de TRC slechts een beperkte mandaatperiode had en daarin moest ze honderden mensenrechtenslachtoffers de gelegenheid bieden in het openbaar te getuigen. De mensenrechtenhoorzittingen vonden plaats van april 1996 tot juli 1997 en in deze zestien maanden moest een maximum aantal mensen aan het woord gelaten worden (Tutu, 1999 en Meiring, 1999). Het getuigen gebeurde dan ook vaak onder tijdsdruk, want de slachtoffers moesten hun verhaal vertellen binnen een strak kader. Door die tijdsdruk moesten de getuigenissen een bepaalde structuur hebben. Binnen die beperkte tijd wilde de TRC namelijk dat bepaalde onderwerpen zeker aan bod kwamen, en daarom moesten de getuigen zich houden aan een vooraf bepaald en duidelijk afgebakend patroon. Deze twee beperkingen waren onvermijdelijk: het doel van de TRC was de slachtoffers zoveel mogelijk vrijheid te geven, maar die vrijheid van expressie moest ietwat beperkt worden om alle getuigen gelijke kansen te geven.

Deze praktische belemmeringen waren echter niet de enige beperkingen die opgelegd werden aan de slachtoffers. Andere beperkingen hadden te maken met de 'hogere' doelstellingen van de Commissie. Het is namelijk meer dan waarschijnlijk dat de TRC haar eigen agendapunten had tijdens de hoorzittingen van het Mensenrechtencomité. Ze wilde de apartheidsslachtoffers niet alleen een platform bieden om hun ervaringen te vertellen; de werking van de TRC had ook algemenere doelstellingen, namelijk afrekenen met het verleden en meewerken aan de bouw van een nieuw Zuid-Afrika. De TRC commissarissen moesten dan ook hun best doen de individuele getuigenissen aan te passen aan een overkoepelende master-story van verzoening en natievorming, en dat kan duidelijk afgeleid worden uit de taal die gebruikt werd tijdens de hoorzittingen.

In dit artikel zal ik het hebben over één bepaalde linguïstische beperking die duidelijk een onderdeel vormde van dat algemenere verhaal dat de TRC trachtte te schetsen. Meerbepaald zal ik hier aantonen op welke manier het concept van verzoening geïntroduceerd werd in de 
getuigenissen van de slachtoffers. In een eerste deel zal ik uitleggen welke technieken de commissarissen gebruikten om verzoening te benadrukken in die getuigenissen; daarna zal ik uiteenzetten wat de contextuele relevantie was van dit verzoeningsdiscours.

\section{VERZOENING ALS TAALKUNDIG CONCEPT}

Het onthullen van zoveel mogelijk waarheid met betrekking tot het apartheidsverleden was volgens het Final Report van de TRC een van de belangrijkste taken van de Commissie. Men veronderstelde dan dat die waarheid cruciaal zou zijn bij het tot stand brengen van verzoening en nationale eenheid in het nieuwe Zuid-Afrika (TRC Final Report, 1998, 1/4: 48). Dit geeft reeds aan dat het concept van verzoening centraal stond in de ideologie van de TRC. De meeste mensen waren het erover eens dat het niet de taak van de Commissie was echt verzoening te creëren in Zuid-Afrika; de TRC werd echter wel verondersteld een proces van verzoening op gang te brengen (o.a. VillaVicencio \& Verwoerd, 2000; Goris, 1999; Parlevliet, 1998; Mxolisi, 2000 en Godobo-Madikizela, 1997). Veel mensen, zowel in ZuidAfrika als erbuiten, zagen de TRC dan ook als het symbolische instrument bij uitstek om verzoening te bevorderen in dit verdeelde land.

De commissarissen waren zich wel degelijk bewust van dit imago van de TRC en ze realiseerden zich dat het verzoeningsconcept prominent aanwezig moest zijn tijdens de zittingen. Dat was dan ook de reden waarom verzoening er erg sterk benadrukt werd - soms zelfs in die mate dat, volgens sommige critici, wraakgevoelens genegeerd werden en slachtoffers bijna verplicht werden dit ideaal van een verzoende Zuid-Afrika te helpen realiseren (Statman, 2000, 23; Van der Merwe, 1999; Stanley, 2001; Arendse, 1997; Hamber \& Wilson, 1999).

Wie de mensenrechtenhoorzittingen bestudeert heeft inderdaad soms de indruk dat verzoening opgedrongen werd bij de slachtoffers. Uit mijn volledige lezing van de meer dan 1800 slachtoffergetuigenissen blijkt dat de totale setting van het Comité voor Mensenrechtenschendingen gericht was op het vestigen van een verzoeningssfeer. In 
de overgrote meerderheid van de hoorzittingen probeerde men een verzoeningsgezind klimaat op te wekken, onder andere door het expliciet vermelden van de term verzoening.

Laat ik eerst een paar methodes aanhalen die de commissarissen gebruikten om het verzoeningsconcept te introduceren in de getuigenissen van de slachtoffers.

Bij het lezen van de slachtofferverhalen valt op dat de commissaris op het einde van de getuigenis vaak expliciet vroeg of de getuige al dan niet overwoog de dader te vergeven. Meestal werd die vraag erg zorgvuldig ingeleid: de commissaris informeerde eerst of het slachtoffer bereid zou zijn de dader te ontmoeten, of hij of zij ertoe in staat zou zijn te praten met de dader, of zijn hand te schudden; soms bood de Commissie steun aan bij het organiseren van zo'n ontmoeting; en uiteindelijk werd dan de vraag gesteld met betrekking tot verzoening met de dader. Op die manier werden slachtoffers voorzichtig begeleid in de richting van het cruciale onderwerp, namelijk de vraag of verzoening aanvaard of verworpen werd. Het is dan vanzelfsprekend dat de meeste slachtoffers instemden zich te verzoenen met de dader. Het feit alleen al dat de commissarissen hier expliciet om vroegen kan gezien worden als een subtiele manier om het concept van verzoening op te dringen. Gelet op de context van de TRC, waarin verzoening duidelijk gepromoot werd, moesten de slachtoffers erg zelfverzekerd en standvastig zijn om te weigeren zich te verzoenen met de dader. Sommige getuigen hadden die psychologische kracht, bijvoorbeeld Bettina Mdlalose, die getuigde over de dood van haar zoon, in het stadje Vryheid in april 1997 (Durban, Vryheid, 17/4/1997) ${ }^{55}$. Op het einde van haar getuigenis zei de commissaris:

COMMISSIONER: But one question I would like to ask is that, if today those perpetrators could come forth and say, "Commission, because you exist today, we would like to go and meet Mrs Mdlalose to ask for forgiveness," would you be prepared to meet with the perpetrators? I know they haven't come forward, they have not even admitted an application for

${ }^{55}$ De fragmenten gebruikt in dit artikel zijn afkomstig van de transcripties die te vinden zijn op de officiële TRC website. Ik verwijs naar de desbetreffende hearing met dezelfde tijd- en plaatsaanduiding als op de site. 
amnesty, but still we would like to ask from you, to get a view from you that if they come to you and ask for forgiveness would you be prepared to sit down with them, shake hands with them, and reconcile with them? Would you be prepared to talk to them?

Bettina Mdlalose antwoordde dan met deze woorden:

MRS MDLALOSE: I don't think I will allow such an opportunity.

Een ander voorbeeld komt van Emily Siko, wiens familie aangevallen werd door de extreem-rechtse Afrikaner Weerstandsbeweging. Ook deze dame is in staat de aandringende toon van Commissaris Manthata te weerstaan (Johannesburg, Klerksdorp, 25/9/1996):

MR MANTHATA: Do you think there is a possibility of reconciliation with these people?

MRS SIKO: No, I don't think so.

MR MANTHATA: Is there any communication between your ministers and their ministers?

MRS SIKO: No.

MR MANTHATA: Are you saying no or you do not know?

MRS SIKO: No, the AWB people don't mix with other ministers from other churches.

Voor de meeste getuigen was het echter zeer moeilijk te weerstaan aan de druk om te verzoenen. Dat was bijvoorbeeld het geval met Gladys $\mathrm{Papu}$, wiens echtgenoot gedood werd door een bende. Op de volgende manier informeerde Commissaris Xundu naar verzoening (East London, King Williamstown, 12-14/5/1997): 
REV XUNDU: Thank you Mr Chairperson. Mam, I heard your story. I only have one question. According to you what can be done so that there can be peace? Is there a conflict between yourself and this other group?

MRS PAPU: What I want is for them to come forward to tell the truth.

REV XUNDU: You are saying that reconciliation can be built if they can come forward?

MRS PAPU: Yes, if they can come and tell the truth.

REV XUNDU: If they can come forward you will forgive them?

MRS PAPU: Yes.

REV XUNDU: Thank you.

Ook aan Adelaide Bungane, die vertelde over haar zoon omgekomen in ballingschap, werd expliciet gevraagd te vergeven (East London, Lusikisiki, 24-26/3/1997):

ADV SANDI: You heard Mrs Matandela (the previous witness) say that these people should come forward, the perpetrators, and ask for forgiveness to the victims. (italics are mine)

MRS BUNGANE: I hear her saying that today. We don't live in the same area. Yes, I heard her.

ADV SANDI: What do you think about that request that the perpetrators should come forward asking for forgiveness?

MRS BUNGANE: It should be so that we can have peace in our hearts. They must ask for forgiveness. 
In deze twee laatste fragmenten zien we duidelijk hoe de commissarissen de woorden van vergiffenis en verzoening bijna letterlijk in de mond leggen van de getuigen ${ }^{56}$. Het was dan bijna onmogelijk om te reageren tegen deze verzoeningssfeer, noch om te proberen de taal van de commissarissen op een of andere manier af te zwakken. Wat in het oog springt, is dat Mrs Papu ook nog uitdrukkelijk door Commissaris Xundu wordt bedankt voor haar welwillendheid om de daders te vergeven.

Er waren echter ook slachtoffers die wel haat- of wraakgevoelens uitten in de loop van hun getuigenis. Opvallend is dan dat die gevoelens zelden ernstig werden genomen. Meestal gingen de commissarissen gewoon verder met het interview en in plaats van enig begrip te tonen voor de emoties van de getuigen bleven ze benadrukken dat de slachtoffers toch vooral zouden moeten proberen te verzoenen. Een voorbeeld hiervan kan gevonden worden in de getuigenis van Nelson Jantjie. Hij getuigde in Kaapstad over de moord op zijn zuster (Cape Town, Karoo, 8/10/1996):

MR JANTJIE: I am angry, I am not working - I have been tortured by police, I suffer, I am of ill health, I am unemployed, I suffer, my kidneys are not all right.

MS SEROKE: We understand - we understand.

MR JANTJIE: These people - the perpetrators they are alive, what are you doing about them - my life is ruined, what are you doing about them? They were not even jailed, I could not even go to my sister's funeral, I was in detention. They were trying to cover up their filth - together with their Magistrate and their Judge, I was used as escape route - to cover up their filth. They wanted to save the man who had shot my sister. Who is guilty - who is guilty. Who is guilty - who is guilty.

\footnotetext{
${ }^{56}$ In overeenstemming met vb Yandell (1998: 45) en Shriver (1998: 136) kunnen we vergiffenis beschouwen als een noodzakelijke - maar niet voldoende - voorwaarde voor verzoening. Zowel de verwijzingen naar verzoening als naar vergiffenis kunnen dus gezien worden als deelaspecten van het TRC verzoeningsdiscours.
} 
She was picked up from the streets, who is guilty - even if she had verbally offended someone - no-one had the right to shoot her, that is nonsense. I do not want to say anymore, I've had it.

MS SEROKE: Mr Nelson we understand your situation.

MR JANTJIE: I am in pain, this police that tortured me, they are working, I am unemployed, these people walk past me everyday, the others are in De Aar - they still under employment, I cannot work for myself because of them. I don't gain anything from that - my children they all over the streets, they are criminals, they do not go to school.

MS SEROKE: We understand your pain, but we ask that you try to control yourself. So that even when we ask our investigation team to find - to find out what happened, we as the Truth Commission would like to reach a place where there can be peace and forgiveness.

Een ander opvallend voorbeeld is de getuigenis van Nhlanhla John Buthelezi. Hij werd gearresteerd en gemarteld en daarna beschouwd als een politiespion door het ANC (Johannesburg, Duduza, 4/2/1997):

MR BUTHELEZI: What I will say is that I was so much assaulted, harassed and I was going through sufferings and people would point fingers at me saying I am a traitor, an informer, calling me a sell-out. Even to date, I still feel bad about that and they make me even want to kill those people. I underwent such a tragedy, you do not understand. On the other side were Comrades, on the other hand there were police. You can't imagine what I was going through.

MR LEWIN: Could we ...

MR BUTHELEZI: I suffered a lot, I almost was affected mentally. Even today, I think somehow I am affected 
mentally. So, I am not going to, I am not going to reconcile, I am not about to.

MRS SEROKE: Order please, order.

CHAIRPERSON: Buthelezi, could you, I think you have come to the end, could you please take questions. Thank you.

In beide voorbeelden zien we dat de haat van de slachtoffers totaal wordt genegeerd. Hun gevoelens worden niet erkend en Mr Buthelezi wordt zelfs onderbroken in het midden van zijn relaas. Nochtans kampen de slachtoffers hier met erg sterke emoties; dat blijkt vooral bij Nelson Jantjie uit de herhaling van de zin 'Who is guilty?' en uit de discursieve tegenstelling tussen ' $T$ en 'they' (de daders van zijn zusters moord). Deze kenmerken wijzen vaak op een verhoogde emotionaliteit en hier zijn dat duidelijk gevoelens van woede. Als een getuige wraakgevoelens had zouden de commissarissen meer informatie hebben kunnen vragen, of ze zouden ten minste wat medelijden hebben kunnen tonen. Dit was echter duidelijk niet hun opdracht - er moest alleen rekening gehouden worden met verzoeningsgevoelens. Het is onwaarschijnlijk dat de tijdsdruk een rol speelde bij de reactie van de commissarissen. Noch de getuigenis van Mr Jantjie, noch de getuigenis van $\mathrm{Mr}$ Buthelezi waren extreem lang. Sommige slachtoffers werden veel langer aan het woord gelaten, zonder dat hun verhaal op een dergelijke manier onderbroken of genegeerd werd.

De volgende methode om verzoening te introduceren heeft te maken met de geschreven verklaring van de slachtoffers. Alle slachtoffers hadden een geschreven verklaring ingediend voor ze verschenen voor de TRC. De vragen en opmerkingen die dan aan bod kwamen tijdens de openbare hoorzittingen waren gebaseerd op die verklaringen. Soms lazen de commissarissen fragmenten uit die verklaringen om de getuige te herinneren aan wat hij of zij vroeger had gezegd. In bepaalde gevallen benadrukte de commissaris dat verzoening uitgedrukt was in de geschreven verklaring en dan werd het desbetreffende fragment expliciet voorgelezen. Op die manier moesten mensen toegeven dat ze inderdaad voorstander waren van verzoening, of dat toch 
zeker waren geweest op het moment dat ze hun geschreven verklaring hadden afgelegd. Een voorbeeld van zo'n expliciete verwijzing naar de geschreven verklaring zien we in de getuigenis van Oscarine Gola, wiens zoon om het leven kwam in Bisho (East London, Bisho 1, 10/9/1996):

COMMISSIONER: Would it be all right with you if I read out what you said about the CDF members in your statement, may I read that and then you can tell me whether you agree that it's correctly noted here?

MRS GOLA: Yes, please read it for me.

COMMISSIONER: The statement is as follows: I wish all the CDF members of the 7th September 1992 Bisho massacre who participated in the massacre would come forward and identify themselves so that we could talk peace and reconciliation. Thank you for that. Is there anything else you wish to say to the Commission Ms Gola?

MRS GOLA: I'd forgotten about that part you just read. Yes I do admit that I did say so but I have nothing further at the moment.

Precies hetzelfde gebeurde tijdens de getuigenis van Manzala Dingumhlaba; zij sprak over de marteling van haar vader (East London, Lusikisiki, 24/3/1997). Commissaris Crichton begint met deze woorden:

MS CRICHTON: I want to ask you a question, because in your statement you said something that has interested me deeply and I want not only the Commission to hear this, I want the people that are listening to this across South Africa to hear it as well, because there is a need for them to hear it. May I quote from what you said in your statement about the perpetrators? In your statement you said: "I wish that the 
perpetrators would ask for forgiveness and compensate me for the loss of my father and the humiliation that they caused."

Do you remember saying that?

MS DINGUMHLABA: Yes I remember.

MS CRICHTON: Is that still your wish?

MS DINGUMHLABA: Yes, I want them to ask for forgiveness, because we are left as orphans.

MS CRICHTON: Thank you very much. Thank you Mr Chairman.

Door die fragmenten uit de geschreven verklaring voor te lezen konden de getuigen niet meer terugkomen op die vroeger geuite gevoelens. Er stond zwart op wit dat een persoon vergevingsgezind was - het voorlezen zorgde er ook voor dat iedereen daarvan nu op de hoogte was - en dat papieren bewijs tegenspreken zou gezichtsverlies betekenen, iets wat de meeste mensen niet aankonden voor het oog van vrienden en buren en van de internationale pers.

Een laatste techniek waardoor de TRC deze verzoeningssfeer probeerde tot stand te brengen heeft te maken met de afsluitende zinnen van de commissarissen. Op het einde van de meeste getuigenissen benadrukten de commissarissen namelijk sterk het verzoeningsconcept. Ze deden dat bijvoorbeeld door het slachtoffer uitdrukkelijk te prijzen als die enig teken van vergiffenis had getoond. Daardoor werd verzoening eens te meer beklemtoond en werd het de volgende getuige erg moeilijk gemaakt haat uit te drukken.

Een voorbeeld hiervan kwam voor tijdens de getuigenis van Christian Peter Meyer, die het verhaal vertelde van de moord op zijn broer en zijn schoonzus. Hij sprak duidelijk in een geest van verzoening en daarnaar werd verwezen door de commissaris in diens afsluitende woorden (East London 2, 12/6/1997): 
COMMISSIONER: Mr Meyer, thank you very much for appearing before the Commission today and for taking our eyes and our minds back to this event that struck the whole world, really. I have been particularly touched by your last paragraph where you say that you are not being driven by vengeance and a desire for revenge, but you are gladdened to coming before the Commission, because you have got this quest for real reconciliation. You have touched us and I suppose that all who have listened to you this morning are going to be equally, are being equally touched by the spirit in which you have made your submission.

Een laatste voorbeeld kunnen we vinden in de getuigenis van $\mathrm{Mr}$ Buthelezi; ook hij werd gearresteerd en gemarteld door de politie. Op deze manier sloot de commissaris de getuigenis af (Durban,Vryheid, 18/4/1997):

COMMISSIONER: And one thing I would like to compliment about you. According to your statement you do say that in spite of all this you still don't hate anyone and you don't hold any grudges against anyone, and you are prepared to forgive everyone who comes to you. That we appreciate a great deal because only a few people think that way. After all the ordeal that you have gone through you are still prepared to shake hands and talk to people and look at things positively. I will now hand you over to the Chairlady.

Uit al deze voorbeelden blijkt dat het concept van verzoening erg sterk werd benadrukt tijdens de openbare hoorzittingen; in sommige gevallen kunnen we zelfs spreken van een opdringen van verzoening. Hier werden slechts een paar voorbeelden aangehaald, maar zij zijn representatief voor de meeste zittingen van het Mensenrechtencomité. 


\section{OORZAKEN VOOR DEZE TAALKUNDIGE MANIPULATIE}

De redenen voor dit soort taalgebruik zijn duidelijk verbonden met de historische context. Het was een van de doelstellingen van de Commissie een proces van verzoening op te starten en de TRC werd gezien als het belangrijkste instrument om die bereidheid tot verzoenen bij de Zuid-Afrikanen te symboliseren. De situatie vereiste dus dat de commissarissen een evenwicht vonden tussen, aan de ene kant, toelaten dat de getuigen hun oprechte gevoelens openlijk konden uiten - zelfs als dit wraakgevoelens waren -, en aan de andere kant hen te verplichten verzoening uit te drukken. De commissarissen moesten een manier vinden om die persoonlijke verhalen te laten aansluiten bij het algemenere 'natieverhaal' van verzoening. Als getuigen spontaan vergevingsgezind waren, was het vrij gemakkelijk dat evenwicht te vinden. Bij haatdragende slachtoffers was het moeilijker het individuele verhaal en de master-story te overbruggen. In de meerderheid van de gevallen was de verzoeningssfeer echter zo overweldigend dat de slachtoffers vrij spontaan meewerkten.

We moeten er wel rekening mee houden dat er grote verschillen merkbaar zijn tussen het taalgebruik van de commissarissen onderling. Sommige commissarissen, bijvoorbeeld bisschop Tutu en Alex Boraine, waren erg bekommerd om verzoening. Als zij slachtoffers begeleidden bij het getuigen verwezen zij dikwijls expliciet naar de concepten van verzoening en vergiffenis. $\mathrm{Zij}$ besteedden meestal ook veel aandacht aan die concepten in hun afsluitende woorden. Voor andere commissarissen daarentegen leek verzoening veel minder belang te hebben; zij vergaten er soms naar te vragen en ze waren meestal ook gematigder in het prijzen van de verzoening uitgedrukt door getuigen. Ik zal nu niet dieper ingaan op dit aspect, maar het is duidelijk dat de professionele achtergrond van de commissarissen hierin een toonaangevende rol speelde.

Alle commissarissen besteedden aandacht aan verzoening, maar voor geestelijken, zoals Tutu en Boraine, leek het een grotere prioriteit.

Samenvattend kunnen we dus stellen dat het verzoeningsconcept inderdaad vaak opgedrongen lijkt te worden aan de getuigen. Het is 
echter een feit dat de commissarissen verplicht waren de vrije meningsuiting van de slachtoffers in zekere mate te beperken zodat een verzoenende sfeer werd gecreëerd, noodzakelijk voor de toekomst van het land.

Deze bekommernis om de toekomst van het land was een aspect van de historische context dat het TRC discours beïnvloedde, en dat het noodzakelijk maakte het verzoeningsconcept te introduceren. Daarnaast speelden echter ook politieke aspecten een rol. Het is duidelijk dat de commissarissen verzoening niet alleen beklemtoonden uit bezorgdheid om 'de toekomst en het welzijn van het land', maar ook omdat dit concept aansloot bij de ideologie van de heersende politieke partijen. Politieke ideologie en politieke macht maken ook deel uit van de historische context en ze oefenen dus invloed op de taal die gebruikt wordt in een bepaalde periode. Hierover is uitgebreid onderzoek gedaan in de domeinen van de discourse analysis en de critical discourse analysis (o.a. Fairclough, 1995; Cameron, 2001; Blommaert \& Bulcaen, 2000). Vanuit dit politieke perspectief is het geen toeval dat de master-story die de TRC probeerde tot stand te brengen vooral betrekking had op verzoening. Het verzoenen van de verschillende maatschappelijke groepen was een belangrijk onderdeel van het politieke programma van de nieuwe regering. Die regering moest bewijzen dat ze het land kon besturen zonder dat dit uit elkaar viel en ze moest ook aantonen dat ze de zwarte meerderheid, die ze beweerde te vertegenwoordigen, in de hand kon houden. Verzoening in Zuid-Afrika was dus absoluut noodzakelijk voor de geloofwaardigheid van de Zuid-Afrikaanse regering, zowel op nationaal als op internationaal vlak. De TRC was het resultaat van onderhandelingen tussen leden van die nieuwe regering. Bovendien was de Commissie het symbolische bewijs dat Zuid-Afrika's overgang naar democratie een succes was. Het is dus begrijpelijk dat het discours gecreëerd in de TRC hoorzittingen gebruikt werd om dat politieke programma te ondersteunen.

Volgens onder andere Foucault (1969), Gramsci (Ransome, 1992) en Bourdieu (1991), wordt taal vaak gebruikt door instellingen om hun hegemonische macht impliciet te realiseren of te handhaven (Philips, 1989). In de bestaande literatuur wordt dan meestal verwezen naar juridische of pedagogische instellingen; zij gebruiken discours dikwijls om hun hegemonie te vestigen door middel van dialoog in 
plaats van door middel van geweld. Bij het analyseren van het TRC discours zien we dat, door het opleggen van verzoening in de taal van de Mensenrechtenhoorzittingen, de TRC ook beschouwd kan worden als een instelling die betrokken was in dat soort van hegemonisch constructivisme. Door de verzoeningsboodschap te beklemtonen vergrootte de TRC niet alleen haar eigen populariteit, maar ze versterkte ook de dominantie van de politieke constellatie waardoor ze in het leven was geroepen.

Hoewel de TRC dus wel volhield dat ze onpartijdig was, suggereert een discursieve analyse van de hoorzittingen dat de Commissie toch gebruikt werd om de dominantie van de heersende partijen in stand te houden.

\section{CONCLUSIE}

Tot besluit van dit artikel is het belangrijk nog eens de dubbelzinnige aard van het TRC discours te benadrukken. Ik heb me hier toegelegd op een vrij negatief en ook controversieel aspect van dat taalgebruik. Aan de hand van de fragmenten heb ik namelijk proberen aan te tonen dat de vrije meningsuiting van de slachtoffers aan banden werd gelegd, en dit niet alleen in naam van het algemeen welzijn, maar ook om de macht van een politieke constellatie te ondersteunen. Deze kritiek mag echter nooit voorbijgaan aan het feit dat dit verzoeningsdiscours ook ongekende vrijheden verschafte aan de getuigen. Hun taal werd dan wel op een bepaalde manier bijgestuurd, maar het feit alleen al dat ze konden getuigen was voor de grote meerderheid van deze mensen een onvergetelijke ervaring. Dit verzoeningsdiscours was dus een erg complex fenomeen: op metaniveau vormde het een hoogtepunt van mogelijkheden wat betreft verbale expressie - zeker vergeleken met de zwijgcultuur die vroeger opgelegd werd door het apartheidsregime. Op microniveau werden die mogelijkheden dan in zekere mate beknot door ze aan te passen aan de socio-politieke realiteit. Het is evident dat de positieve aspecten zwaarder doorwegen, maar dat betekent niet dat we moeten terugschrikken voor constructieve kritiek.

Het is ook duidelijk dat deze ambigue taalsituatie een weerspiegeling is van het TRC fenomeen in zijn geheel. De hoofdbekommernis van 
de Commissie was inderdaad een open forum te bieden voor de slachtoffers van apartheid. Die onderliggende theorie was een van de bestaansredenen van de Commissie. Blijkbaar was het echter niet eenvoudig die theorie om te zetten in praktijk. Financiële beperkingen en politieke belangen verplichtten de Commissie afbreuk te doen aan de vooropgestelde idealen.

Aangezien de Zuid-Afrikaanse Waarheids- en Verzoeningscommissie steeds vaker als model wordt beschouwd voor commissies wereldwijd, is het noodzakelijk inzicht te verschaffen in de onderliggende motivaties van een dergelijke instelling. De TRC was een nobel en lovenswaardig initiatief, wat niet weglaat dat haar tekortkomingen ons lessen kunnen leren voor de toekomst.

\section{BIBLIOGRAFIE}

ARENDSE, CRAIG, 1997. Mending the Vase. Reconciling broken relationships. Track Two 6/3\&4: 29.

ASMAL, KADER, LOUISE ASMAL \& RONALD SURESH ROBERTS, 1997. Reconciliation Through Truth, a Reckoning of Apartheid's Criminal Governance. Cape Town: David Philip Publishers.

BLOMMAERT, JAN \& CHRIS BULCAEN, 2000. Critical Discourse Analysis. Annual Review of Anthropology 29: 447-466.

BORAINE, ALEX, 2000. A Country Unmasked. Inside South Africa's Truth and Reconciliation Cape Town: Oxford University Press.

BOURDIEU, PIERRE, 1991. Language and symbolic power. Cambridge: Polity Press.

BUUR, LARS, 2000. Institutionalising truth. Victims, perpetrators and professionals in the everyday work of the South African Truth and Reconciliation Commission. PhD Dissertatie, Aarhus University, Denemarken.

CAMERON, DEBORAH, 2001. Working With Spoken Discourse. London: SAGE Publications.

EYSKENS, LISBETH, 2001. Controversies over de Zuid-Afrikaanse Waarheids- en Verzoeningscommissie. Licentiaatsverhandeling. Gent: Universiteit Gent, Faculteit Politiek en Sociale Wetenschappen. 
FAIRCLOUGH, NORMAN, 1995. Critical Discourse Analysis. The Critical Study of Language. London: Longman Group Limited.

FOUCAULT, MICHEL, 1969. L'archéologie du savoir. Paris: Bibliothèque des Sciences Humaines.

GODOBO-MADIKIZELA, PUMLA, 1997. Healing and the racial divide? Personal reflections on the Truth and Reconciliation Commission. South African Journal of Psychology 27/4: 271-276.

GORIS, GIE, 1999. Geen paradijservaring, Zuid-Africa's poging tot verzoening. Wereldwijd februari 1999: 42-43.

HAMBER, BRANDON \& RICHARD WILSON, 1999. Symbolic Closure through Memory, Reparation and Revenge in Post-conflict Societies. Paper presented at the Traumatic Stress in South Africa Conference. Parktonian Hotel, Johannesburg, South Africa, 27-29 January 1999.

HAYNER, PRISCILLA B., 2000. Unspeakable Truths. Confronting State Terror and Atrocity. London: Routledge.

KLERK DE, VIVIAN, 2003a. Language and the law. Who had the upper hand? AILA Review 16: 89-103.

KLERK DE, VIVIAN, 2003b. The language of truth and reconciliation: was it fair to all concerned? Southern African Linguistic and Applied Language Studies 21/1\&2: 114.

MEIRING, PIET, 1999. Chronicle of the Truth Commission. Vanderbijlpark: Carpe Diem Books.

MERWE VAN DER, HUGO, 1999. The Truth and Reconciliation Commission and Community Reconciliation: An Analysis of Competing Strategies and Conceptualisations. Dissertation submitted in partial fulfilment of the requirements of the degree of PhD at the George Mason University.

MXOLISI, MGXASHE, 2000. Reconciliation: a call to action. In Charles VillaVicencio \& Wilhelm Verwoerd (eds.) Looking Back, Reaching Forward, Reflections on the Truth and Reconciliation Commission of South Africa. 210-218. Cape Town: University of Cape Town Press.

PARLEVLIET, MICHELLE, 1998. Considering Truth. Dealing with a Legacy of Gross Human Rights Violations. Netherlands Quarterly of Human Rights 16/2: 141174. 
PHILIPS, SUSAN U., 1998. Language Ideologies in Institutions of Power: A Commentary, in Bambi B. Schieffelin, Kathryn A. Woolard \& Paul V. Kroskrity (eds.) Language Ideologies. Practice and Theory 211-228. New York: Oxford University Press.

RANSOME, PAUL, 1992. Antonio Gramsci. A New Introduction. New York: Harvester Wheatsheaf.

RIDDER DE, TRUDY, 1997. 'Vicarious Trauma'. Supporting the TRC Staff. Track Two 6/3\&4.

RIGBY, ANDREW, 2001. Justice and Reconciliation. After the Violence. Boulder: Lynne Riener Publisher.

SHEA, DOROTHEA, 2000. The South African Truth Commission: The Politics of Reconciliation. Washington DC: United States Institute of Peace Press.

SHRIVER JR., DONALD W. 1998. 'Is there Forgiveness in Politics? Germany, Vietnam, and America', in Robert D. Enright \& Joanna North (eds.), Exploring Forgiveness, pp. 131-149. Madison: The University of Wisconsin Press.

STANLEY, ELIZABETH, 2001. Evaluating the Truth and Reconciliation Commission. Journal of Modern African Studies 39/3: 525-546

STATMAN, JAMES, 2000. Performing the truth: the social-psychological context of TRC narratives. South African Journal of Psychology 30/1: 23-45.

THE SOUTH AFRICA PAGE:

http://www.sas.upenn.edu/African_Studies/Country Specific/S Africa.html

TRC RESEARCH WEBSITE, 2004. http://africana.ugent.be/htm

TRC WEBSITE 1998. http://www.doj.gov.za/trc/trc frameset.htm

TRUTH AND RECONCILIATION COMMISSION OF SOUTH AFRICA FINAL REPORT, 1998. London: Macmillan.

TUTU, DESMOND MPILO, 1999. No Future Without Forgiveness. New York: Doubleday.

VILLA-VICENCIO, CHARLES \& WILHELM VERWOERD, 2000. Constructing a Report: Writing Up the 'Truth'. In Robert I. Rotberg \& Dennis Thompson (eds.) Truth versus justice: the morality of truth commissions: 279-294. Princeton: Princeton University Press. 
WILSON, RICHARD A., 2001. The politics of Truth and Reconciliation in South Africa. Legitimising the Post-Apartheid State. Cambridge: Cambridge University Press.

YANDELL, KEITH E. 1998. 'The Metaphysics and Morality of Forgiveness', in Robert D. Enright \& Joanna North (eds.), Exploring Forgiveness, pp. 35-45. Madison: The University of Wisconsin Press. 